GLOBAL JOURNAL OF PURE AND APPLIED SCIENCES VOL. 24, 2018: 191-202

COPYRIGHT@ BACHUDO SCIENCE CO. LTD PRINTED IN NIGERIA ISSN 1118-0579 www.globaljournalseries.com, Email: info@globaljournalseries.com

\title{
CLIMATE VARIABILITY AND GENDER DIFFERENTIALS IN DECISION MAKING PROCESSES AMONG FARMING HOUSEHOLDS IN BARINGO COUNTY, KENYA AND JIGAWA STATE, NIGERIA: A COMPARATIVE ASSESSMENT
}

\section{EZENWA L. I., ONYEGBULAM L. A. AND OMONDI P.}

(Received 24 October 2018; Revision Accepted 16 November 2018)

\begin{abstract}
This paper describes the impact of household activities by gender in areas vulnerable to climatic variability. A multistage sampling technique was applied, using both quantitative and qualitative methods of data collection. Primary data was collected using a structured questionnaire while secondary data was obtained from the Meteorological Department Nairobi, Kenya and Lagos, Nigeria. Data obtained were analysed using frequency distribution, trend analysis, percentage and means. A total of 338 respondents were sampled in Baringo County and 158 respondents in Jigawa State. Trend in rainfall pattern has been unstable and fluctuates by $0.44 \mathrm{~mm}$ and $19.96 \mathrm{~mm}$ in Baringo County, Kenya and Jigawa State, Nigeria respectively. Majority of the respondents $94.1 \%$ (Baringo county) and $60.68 \%$ (Jigawa State) affirmed that the climate is no longer stable following observed variations in the elements of climate over time. Perception of respondents were in line with the climatic data records. A differential assessment on socially contructed roles of male and female respondents in farming households of Baringo County, Kenya revealed that males are key decision makers in choice of crop/seed to plant $(50.6 \%)$, livestock keeping/feeding (57.4\%), land preparation (52.4\%) and coping strategies to adopt for climate variability $(57.1 \%)$. Similarly, males in Jigawa State, Nigeria took charge, leading decisions on crop/seed to plant (60.7\%), livestock keeping/feeding (51.6\%), and coping strategies to adopt for climate variability $(58.8 \%)$ while their females are key decion makers in land preparation activities $(57.5 \%)$. This implies that female decisions (on agricultural activities and climate variability) in the study areas are secondary.
\end{abstract}

KEY WORDS: Climate variability, Livelihood, Gender, Adaptation/coping strategies

\section{INTRODUCTION}

Rural women are resourceful economic agents who contribute to the wellbeing of their families and the growth of communities in many ways, especially in the agricultural and rural economic activities in the developing world (FAO, 2011; IFAD, 2015). They contribute significantly to the food security and income generation of their households, although their roles vary considerably among and within regions. Women's share of the agricultural labour force ranges from approximately 20 per cent in Latin America to almost 50 per cent in East and Southeast Asia and sub-Saharan Africa (FAO, 2011). Despite the amount of work that women perform, their role in agriculture remains largely unrecognized. This situation emanated from norms and traditional patriarchal socially constructed values that skew household decisions in favour of the male counterpart. Intra-household, even when women play key roles in pursuing livelihood strategies for their households, they often have little or no control over the decision-making process regarding incomes derived from their work or family-based activities. As a consequence, they are often excluded or marginalized from decisions on spending priorities and constrained in their asset accumulation, affecting the well-being of all household members, particularly children. Their limited presence and voice in public affairs result in policies,

Ezenwa L. I., Department. of Environmental Management \& Toxicology, Michael Okpara University of Agriculture, Umudike, Abia State, Nigeria.

Onyegbulam L. A., Department. of Agribusiness Management, Michael Okpara University of Agriculture, Umudike, Abia State, Nigeria.

Omondi P., Departments of Geography, Moi University, Eldoret, Kenya 
investments and legal frameworks that are less sensitive to their specific needs and circumstances. Women are often excluded or absent from, or underrepresented, on the decision-making processes in the agrarian communities and other rural entities (IFAD, 2015).

Most recently, global phenomena such as men's migration to cities and seasonal migration are expanding the role of women in the agriculture sector in rural areas (IFAD, 2015). On the heels of a new revolution, Africa is now more than ever tending towards climate-smart agriculture. Evidences from recent events point to the devastating impacts of a changing climate which has ripple effects on livelihoods and food security, and farming communities in the developing countries are worse hit.

African continent is already enmeshed in several crisis, most of which results from the threat caused by climatic variability. Variability in climate is said to occur when climate fluctuates yearly above or below long-term average values (Akinseye et al., 2012; Antwi-Agyei et al., 2014, IPCC, 2014). It causes extreme stress on the economy with the agricultural sector being the most sensitive to climatic variability. Climate variability is aggravated by phenomenal threats, which includes political, socio-economic crisis from the nonclimatic based problems already plaguing the countries in the Africa (Adesina, 2008; Binswanger-Mkhize, 2009). The threat from climate variability would further exacerbate the crisis on the continent by multiplying the vulnerability of the communities. Water supply that is an essential commodity is increasingly lacking, therefore affecting both crop production and animal rearing (FAO AQUASTAT, 2005; Besada and Karolina 2015).

Countries in sub-Sahara Africa carry out their agricultural activities with a heavy dependence on rainfall, which is on the decline. The farmers and pastoralists will have to seek for ways to ameliorate the impacts of climate variability. Although, traditions and culture have placed limitations to the gender based decision making on household and agricultural activities, climate variability will in the future cause changes to those activities in households, especially in areas most vulnerable to climate variability and gain prominence in future decisions to be taken, as most people are diversifying into agro-allied related occupations. It has been noted that the male gender takes most decision as related to household affairs and agricultural issues in Africa but the female bears the burden the more (bearing the difficult tasks). This could be attributed to the fact that most female gender in rural areas spend more time at home (Nhemachena and Hassan, 2007, FAO, 2011b)

Projection shows a decrease in rainfall with substantial increase in temperature for the study locations (IPCC, 2014). Rainfall has been unpredictable and poorly distributed. Locals attested that their locations have experienced drought at various times, which has influenced the roles and activities of different gender (decision-making, socio-economic status, perception and adoption of coping methods). This has placed smallholder farmers in a precarious situation. Access to information on climate variability would help farmers to cope with the effects of climate extremes and provide for best coping strategies. Crop cultivation and livestock rearing are now sources of livelihood of most people in the study locations. Hence, it is important to have good background knowledge in dealing with the situation.

\section{RESEARCH METHODOLOGY}

\section{Study Area}

The study was carried out between March and July 2017 in Marigat and Mogotio sub-county (Baringo County) which is located in North-West Kenya (Map 1). It is a semi-arid area situated at an average altitude of $900 \mathrm{~m}$ above the sea level and lies between latitude $00^{\circ} 26^{\prime}-00^{\circ} 32^{\prime} \mathrm{N}$ and longitude $36^{\circ} 00^{\prime}-36^{\circ} 09^{\prime} \mathrm{E}$ and it is located within agro-climatic zone IV and V (Wasonga, et al., 2011). The area has a mean temperature of about $32.8^{\circ} \mathrm{C} \pm 1.6^{\circ} \mathrm{C}$ with annual average rainfall of $512 \mathrm{~mm}$ occurring in two seasons: March to August and November to December. Baringo is one of the 47 counties in Kenya, situated in the Rift Valley region. It borders Turkana and Samburu counties to the North, Laikipia to the East, Nakuru to the South, Uasin Gishu to the Southwest, and Elgeyo - Marakwet and West Pokot to the West. With an area of $11,075.3 \mathrm{~km}^{2}$, Baringo County has an estimated population of 555,561 (KNBS, 2010).

The study in Nigeria was carried out in three local government areas in Jigawa State, namely: Maigatari, Babura and Sule-Tankarkar (Map 2). Jigawa State is located in the north central region of Nigeria. It is situated between latitude $11^{\circ} \mathrm{N}, 13^{\circ} \mathrm{N}$ and Longitude $8^{\circ} \mathrm{E}, 10.15^{\circ} \mathrm{E}$. A larger part of the state lies in the Sudan savannah while the southern part is majorly guinea savannah. The total annual rainfall ranges from $600 \mathrm{~mm}$ (northern part) to about $1000 \mathrm{~mm}$ (southern parts of the state). It experiences an annual rainfall average of $650 \mathrm{~mm}$ (Bidoli et al., 2012). The maximum temperature reaches $40^{\circ} \mathrm{C}$ around March to September, while the minimum temperature could drop to $19^{\circ} \mathrm{C}$ during October to February.

Jigawa State borders with Kano and Katsina States to the west, Bauchi State to the east and Yobe state to the northeast. To the north, it shares an international border with the Zinder Region of the Republic of Niger. The estimated population of Jigawa state is about $4,348,649$ (NPC, 2006), with an estimated land area of $23,154 \mathrm{~km}^{2}$. 


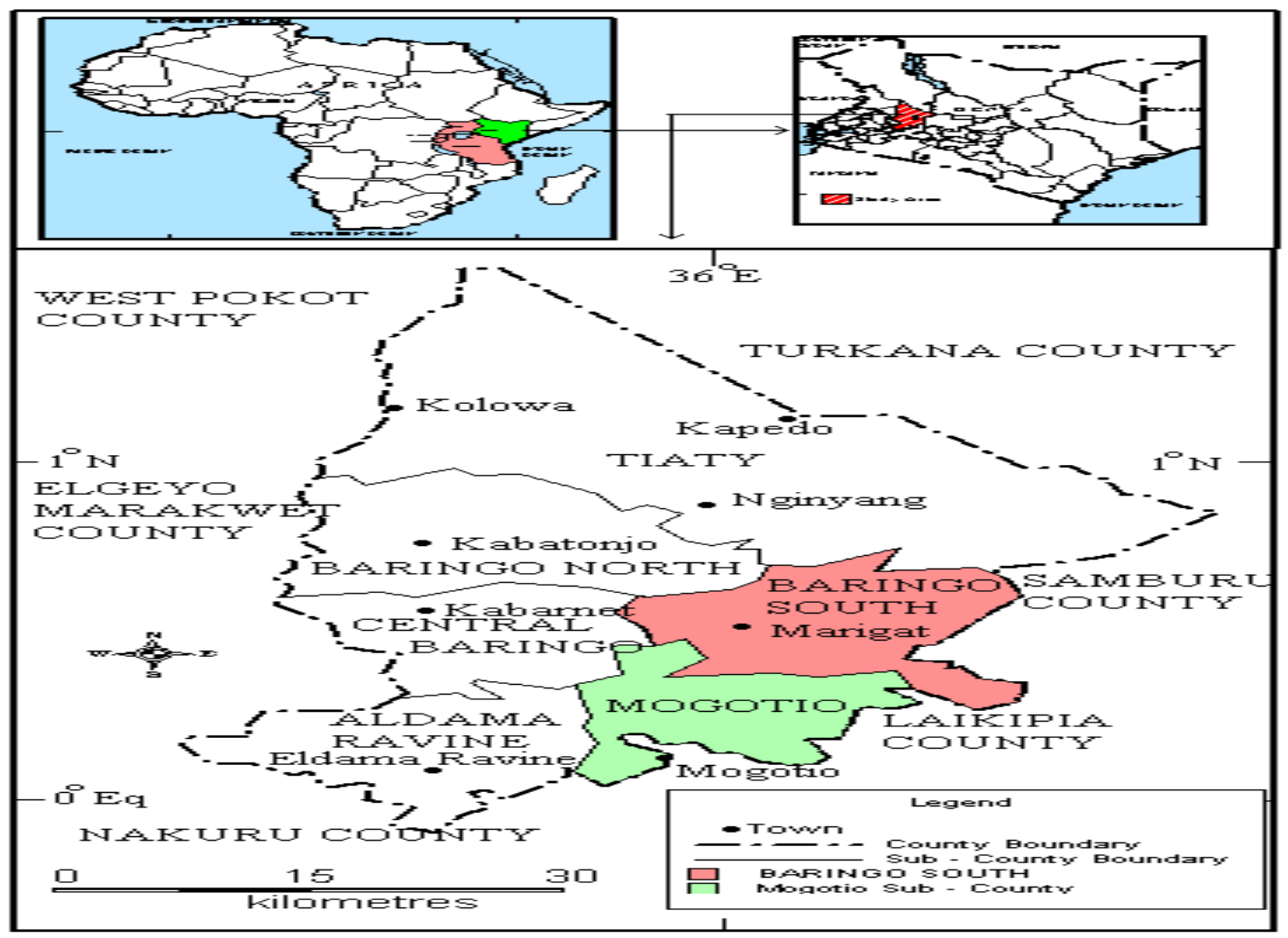

Map 1: Map of Baringo County showing the study locations

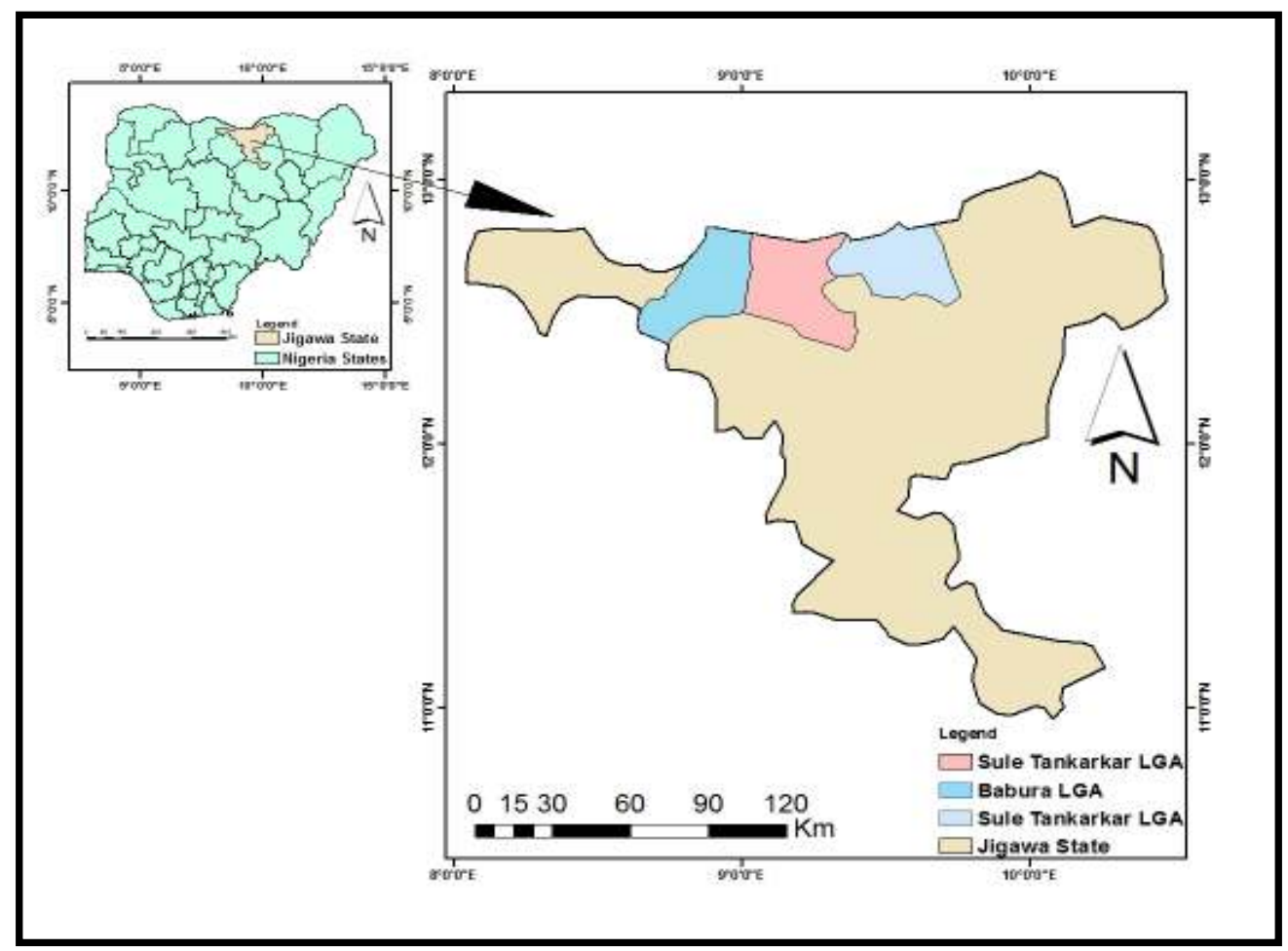

Map 2: Map of Jigawa State showing the study locations 


\section{Sampling Technique and Data collection}

In this study, a multi-stage sampling technique was applied, using both quantitative and qualitative approaches. Primary data was collected using a wellstructured questionnaire while secondary data (31-yearold climatic data) was obtained from Kenyan Meteorological Department, Nairobi and Nigeria Meteorological Agency, Oshodi, Lagos. The validity of the semi-structured questionnaire was pre-tested before it was used in collecting data from the sampled communities and villages. The target population comprised of household heads, father or mother or any adult person in charge (aged 18 years and above) of the household. The qualitative data was obtained using focus group discussions (FGDs) held in different villages to elicit information concerning climate variability impact of drought, livelihood activities as it relates to men and women in the study area. These served as a guide in counterchecking the information that was supplied by each male headed and female headed household in the study area.

\section{Analytical Technique}

Data obtained were analysed using descriptive statistics such as frequency distribution, trend analysis, percentage and means.

\section{Results and Discussions}

Socio-economic Characteristics of the Sampled Population in Study Locations

The distribution of the sampled population in Baringo County, Kenya and Jigawa State, Nigeria by their socioeconomic characteristics is presented in Table 1 below.

Table 1: Socio-economic characteristics of the respondents

\begin{tabular}{|c|c|c|c|c|}
\hline \multirow[t]{2}{*}{ Socioeconomic characteristics } & \multicolumn{2}{|c|}{ Baringo County, Kenya } & \multicolumn{2}{|c|}{ Jigawa State, Nigeria } \\
\hline & Frequency & Percentage & Frequency & Percentage \\
\hline \multicolumn{5}{|l|}{ Gender } \\
\hline Male & 206 & 60.95 & 98 & 64.1 \\
\hline Female & 132 & 39.05 & 55 & 35.9 \\
\hline Total & 338 & 100.00 & 153 & 100.0 \\
\hline \multicolumn{5}{|l|}{ Age } \\
\hline $18-30$ & 38 & 11.24 & 15 & 9.8 \\
\hline $31-40$ & 119 & 35.21 & 42 & 27.5 \\
\hline $41-50$ & 130 & 38.46 & 59 & 38.6 \\
\hline $51-60$ & 41 & 12.13 & 29 & 19.0 \\
\hline$>60$ & 10 & 2.96 & 8 & 5.2 \\
\hline Total & 338 & 100.00 & 153 & 100.0 \\
\hline \multicolumn{5}{|l|}{ Level of Education } \\
\hline No School & 64 & 18.93 & 8 & 5.2 \\
\hline Primary & 103 & 30.47 & 97 & 63.4 \\
\hline Secondary & 128 & 37.87 & 13 & 8.5 \\
\hline Tertiary/College & 33 & 9.76 & 12 & 7.8 \\
\hline University & 10 & 2.96 & 23 & 15.0 \\
\hline Total & 338 & 100.00 & 153 & 100.0 \\
\hline \multicolumn{5}{|l|}{ Marital Status } \\
\hline Single & 60 & 17.75 & 44 & 24.18 \\
\hline Married & 185 & 54.73 & 37 & 28.76 \\
\hline Divorced & 25 & 7.40 & 40 & 26.14 \\
\hline Separated & 25 & 7.40 & 7 & 4.58 \\
\hline Widowed & 43 & 12.72 & 25 & 16.34 \\
\hline Total & 338 & 100.00 & 153 & 100.00 \\
\hline \multicolumn{5}{|l|}{ Household size } \\
\hline $1-5$ & 169 & 50.00 & 115 & 75.16 \\
\hline $6-10$ & 149 & 44.08 & 1 & 0.65 \\
\hline $11-15$ & 15 & 4.44 & 19 & 12.42 \\
\hline $16-20$ & 2 & 0.59 & 10 & 6.54 \\
\hline$>20$ & 3 & 0.89 & 8 & 5.23 \\
\hline Total & 338 & 100.00 & 153 & 100.00 \\
\hline \multicolumn{5}{|l|}{ Occupation of Household Head } \\
\hline Pastoralist & 153 & 45.27 & 127 & 83.01 \\
\hline Agro-Pastoralist & 120 & 35.50 & 9 & 5.88 \\
\hline Business & 35 & 10.36 & 11 & 7.19 \\
\hline Employed & 30 & 8.88 & 6 & 3.92 \\
\hline Total & 338 & 100.00 & 153 & 100.00 \\
\hline \multicolumn{5}{|l|}{ Occupation of Spouse } \\
\hline Pastoralist & 16 & 4.73 & 14 & 9.15 \\
\hline Agro-Pastoralist & 280 & 82.84 & 138 & 90.20 \\
\hline Business & 30 & 8.88 & 1 & 0.65 \\
\hline Employed & 12 & 3.55 & & \\
\hline
\end{tabular}




\begin{tabular}{lllll} 
Total & $\mathbf{3 3 8}$ & $\mathbf{1 0 0 . 0 0}$ & $\mathbf{1 5 3}$ & $\mathbf{1 0 0 . 0 0}$ \\
Ownership of land & & & & \\
Yes & 315 & 93.20 & 104 & 67.97 \\
No & 23 & 6.80 & 49 & 32.03 \\
Total & $\mathbf{3 3 8}$ & $\mathbf{1 0 0 . 0 0}$ & $\mathbf{1 5 3}$ & $\mathbf{1 0 0 . 0 0}$ \\
$\begin{array}{l}\text { Land tenural arrangement } \\
\text { Bought }\end{array}$ & 60 & 17.75 & 48 & 31.37 \\
Rented & 59 & 17.46 & 56 & 36.60 \\
Issued by Govt. Ranch & 9 & 2.66 & 35 & 22.88 \\
Issued by National Irrigation Board & 3 & 0.89 & & \\
Issued by Government & 207 & 61.24 & 14 & 9.15 \\
Total & $\mathbf{3 3 8}$ & $\mathbf{1 0 0 . 0 0}$ & $\mathbf{1 5 3}$ & $\mathbf{1 0 0 . 0 0}$ \\
Size of the Land (ha) & & & & \\
$1-3$ & 145 & 42.90 & - & - \\
$3.1-6.0$ & 88 & 26.04 & - & - \\
$6.1-9.0$ & 24 & 7.10 & 116 & 75.82 \\
$9.1-12.0$ & 25 & 7.40 & 37 & 24.18 \\
$>12.0$ & 56 & 16.57 & - & - \\
Total & 338 & 100.00 & 153 & 100.00 \\
\hline
\end{tabular}

Source: Field Survey, 2017

The result showed that most $(38.46 \%$ and $38.6 \%)$ of the respondents in Baringo County, Kenya and Jigawa State, Nigeria respectively were within the age bracket of $41-50$ years. This implies that the rural population in the study locations were in their active stage of life. They are physically fit to work for a long time, bear risk, be innovative, and have mental capacity to cope with daily challenges; a finding corroborated by Hansen, et al., (2012). In Baringo County, most (54.73\%) of the respondents are married. This implies that married individuals dominated the study area. The plethora of married people has huge implication for family labour supply (Ironkwe and Olojede, 2012). Marriage predisposes an individual to become responsible than the single ones since they must cater for their family needs (Nnamerenwa et al., 2017). The number of family members in the study area shows that most $(50 \%$ and $75.16 \%$ ) of the rural populace in Baringo County, Kenya and Jigawa State, Nigeria respectively had at most 5 persons per household. This implies that the family members were moderately sized. The moderate household size is of benefit to rural populace since it has been observed in various studies, such as Ali and Erenstein (2017), that family labour is most essential in any household business. This helps to reduce the cost of hired labour.

Most of the household heads in Baringo county are pastoralist $(45.27 \%)$, agro-pastoralist $(35.5 \%)$ with others involved in business $(10.36 \%)$ and those employed $(8.88 \%)$, while in Jigawa State most of the household heads are majorly pastoralist $(83.01 \%)$, while others are agro-pastoralist $(5.88 \%)$, business $(7.19 \%)$ and employed $(3.92 \%)$. This implies that the climate of the locations determines largely the livelihood of the rural populace, but with the variability, it positively or negatively influenced. It will be noted that the spouses' occupation of the most of the household heads are involved in agro-pastorialism, with Baringo County and Jigawa State recording $82.84 \%$ and $90.20 \%$ respectively. In Jigawa state $0.65 \%$ of the spouses are involved in business $(0.65 \%)$, which validates the definition of the area as an agrarian region but some of the spouses of the household head in the Baringo County still do business $(8.88 \%)$ and few are employed $(3.55 \%)$. This helps them to support their spouses when the yield of crop decline due to climatic adversity. Most of the land put to use in the Baringo County were either bought or rented, constituting $17.75 \%$ and $17.46 \%$ respectively, implying that there are enough lands to grow crops and rear livestock. However, in Jigawa state, most of the rural populace rent the land where they use $(36.60 \%)$ and some have to buy the land $(31.37 \%)$. A contrast can be seen in size of land used between the two locations, in Jigawa state most of the farmers $(75.8 \%)$ have large farm size $(6.1-9.0$ ha), while $24.18 \%$ have farmland that is quite large $(9.1-12.0 \%)$. In the Baringo County, most $(42.9 \%)$ of the farmers operate on small size of land (1-3 ha), while $26.04 \%$ uses 3.1 -6 ha, discouraging large-scale food production with climatic fluctuation biting harder, large area is needed to grow more crops and raise more livestock to ensure food sufficiency especially as most of the populace are involved in livestock keeping and crop production (Gonzalez, 2007 and Alemu et al., 2007). 
Household Perception of Rainfall and Temperature in Baringo County, Kenya and Jigawa State, Nigeria The distribution of the sampled population by their perception on rainfall in Baringo County, Kenya and Jigawa State, Nigeria is presented in figure 1.

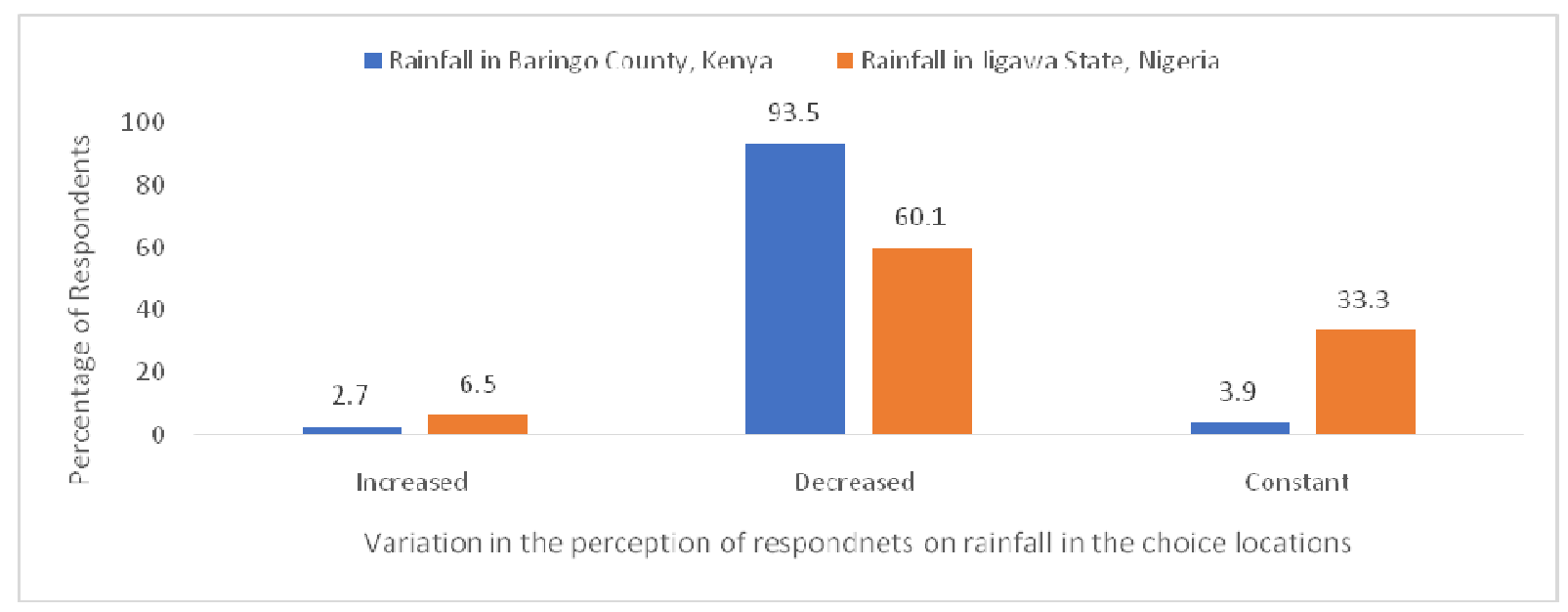

Figure 1: Perception of Rainfall in Baringo County, Kenya and Jigawa State, Nigeria

Figure 1 showed that most $(93.5 \%$ and $60.1 \%)$ of the sampled population in Baringo County, Kenya and Jigawa State, Nigeria respectively observed that there is a decrease in rainfall. This depicts that there is possibility of serious drought occurring in Baringo County and Jigawa State in years to come, if the trend of rainfall in these study locations do not reverse upward in the succeeding years. This decrease in rainfall will affect both crop production and livestock keeping negatively since agriculture in Kenya and Nigeria are rain-fed dependent. This finding is consistent with Cooper and Coe (2011), Ayugi et al., (2016), Recha et al.,(2016); Odjugo (2010), Oguntade et al., (2012) and Chung et al.,(2018) whose works also observed that there is decrease in rainfall amount in Kenya and Nigeria in the recent years caused by climatic variability.

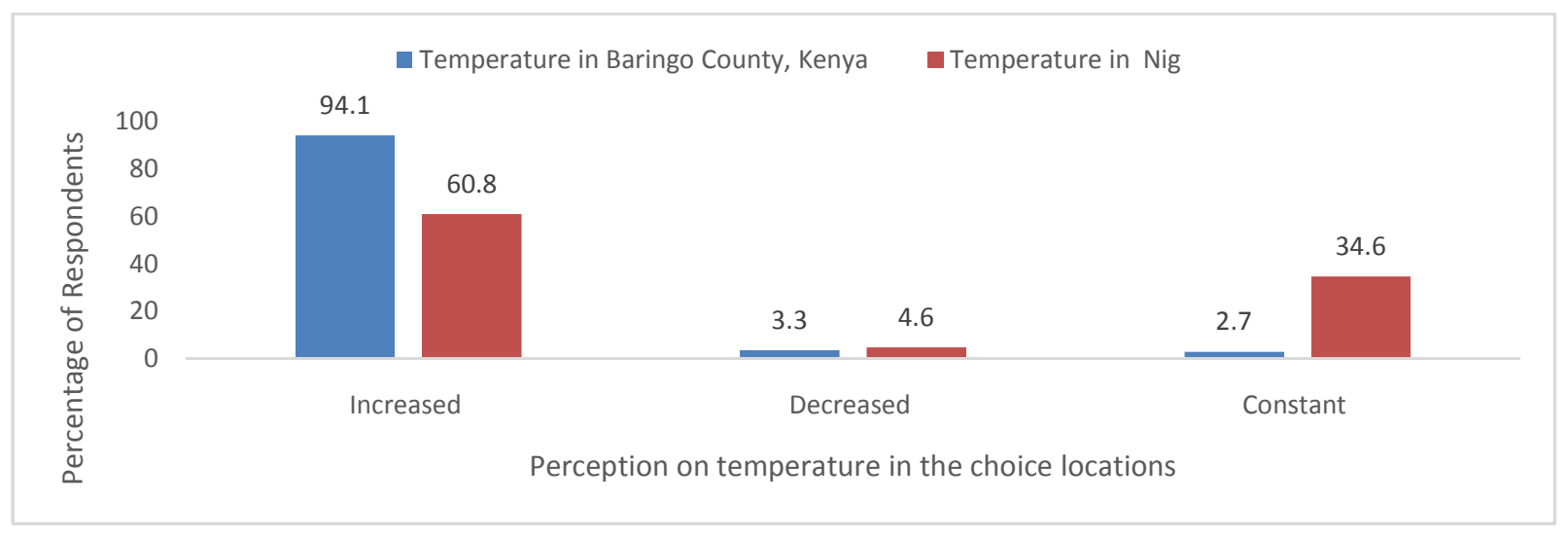

Figure 2: Perception of Annual Temperature in Baringo County, Kenya and Jigawa State, Nigeria over time

Figure 2 shows that $(94.1 \%$ and $60.8 \%)$ of the respondents in Baringo County, and Jigawa State, respectively observed that there has been an increase in temperature in the last few seasons. , leading to prevalence of diseases such as heat rashes, measles, etc. Wilting of trees, flowers and leaves were observed in both Baringo county, and Jigawa state, which was attributed to high temperature (Epstein, 2002; McMichael et al., (2006); Sawa and Buhari, (2011); Ostfeld and Brunner, 2015). As at the month of June, 2017, the soil was observed to be dry with no visible signs of rain and this could be attributed to high temperature and low rainfall in both study areas. Verification of the certitude in the observations of the respondents on climate variability in the study areas was made by collecting a thirty-two years' data on rainfall and temperature from the meteorological station located at Nairobi, Kenya and Meteorological stations in Lagos State, Nigeria for Jigawa State climatic data, which covers the meteorological conditions of the studied area. Figures 3 and 4 represent the thirty-two (32) years mean monthly data on rainfall and temperature in Baringo County, Kenya and Jigawa state, Nigeria. 


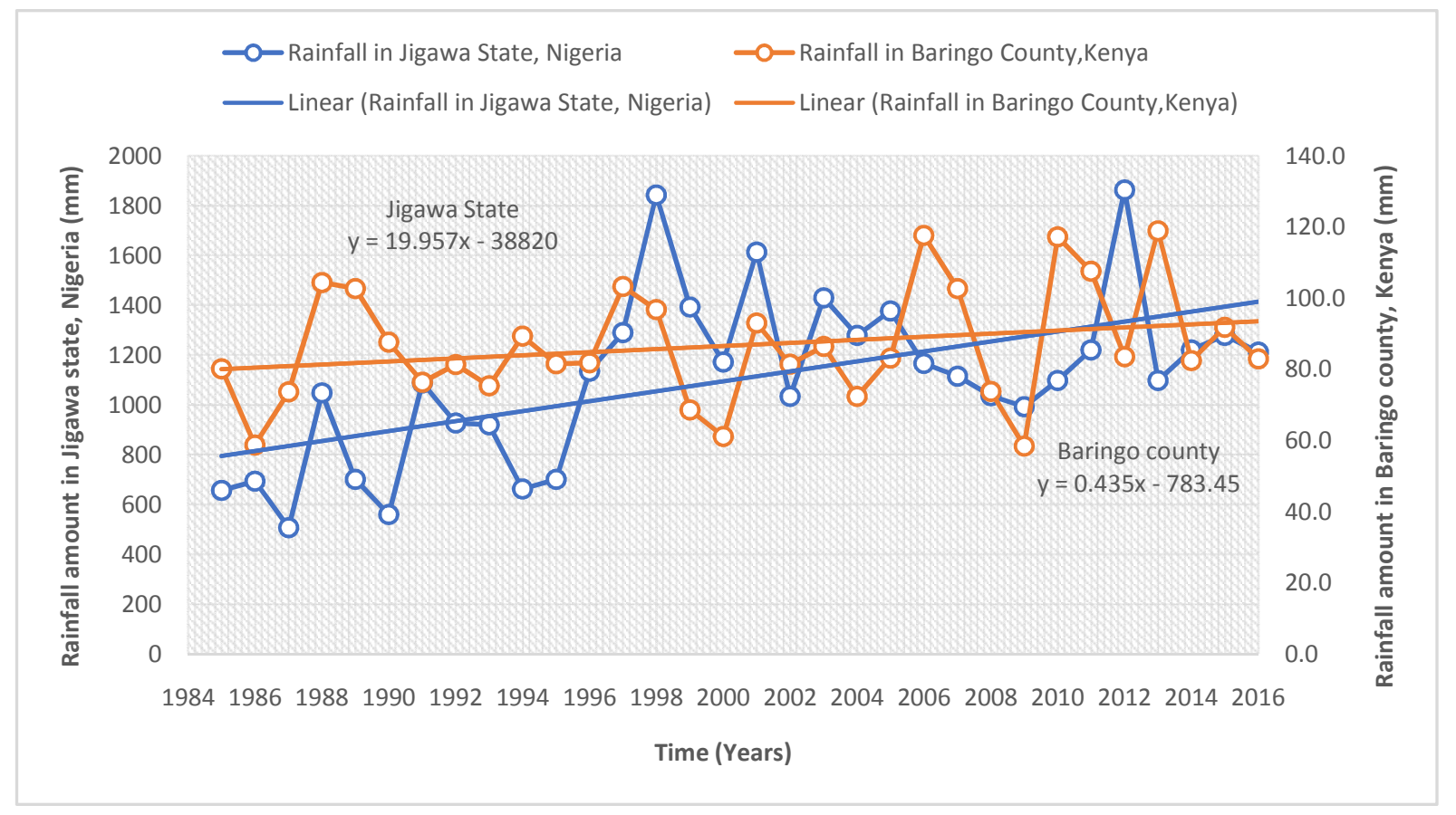

Figure 3: Mean variation in the annual rainfall $(\mathrm{mm})$ in Baringo County, Kenya and Jigawa State, Nigeria

The trend analysis of the annual rainfall in Baringo County, Kenya from 1984 - 2016 shows a fluctuation with increased annual rainfall (Figure 3). This volume of annual rainfall declined from 80.1 millimetres in 1985 to 58.7millimetres in 1986, and increased to 104.3millimetres in 1988, before decreasing again to 76.3 millimetres in 1991. The volume of rainfall in Baringo county fluctuated more between 2001 and 2003 and thereafter increased steadily from $72.3 \mathrm{~mm}$ in 2004 to $117.6 \mathrm{~mm}$ in 2006 , but later declined to $58.4 \mathrm{~mm}$ in 2009 before skyrocketing to as high as $117.2 \mathrm{~mm}$ in 2010 and to its highest volume of $118.9 \mathrm{~mm}$ in 2013. However, there was a decrease in the volume of rainfall in Baringo County since 2016. A $6.31 \%$ variation in volume of rainfall in Baringo County was explained by changes in time. A unit change in time causes the volume of rainfall to decrease by $0.435 \mathrm{~mm}$. This depicts a scenario of drought occurring in Kenya. This result is consistent with the finding of Souverijns et al., (2016) and OXFAM (2017), which observed that the frequency of drought due to reduced amount of rainfall and other extreme climate events in Kenya is increasing.

Similarly, the amount of rainfall in Jigawa state, Nigeria fluctuated between 1985 and 2016. A 31.72\% variation in the amount of rainfall in Jigawa state was explained by changes in time. A unit change in time causes the amount of rainfall in Jigawa State to either decrease or increase by $19.957 \mathrm{~mm}$. 


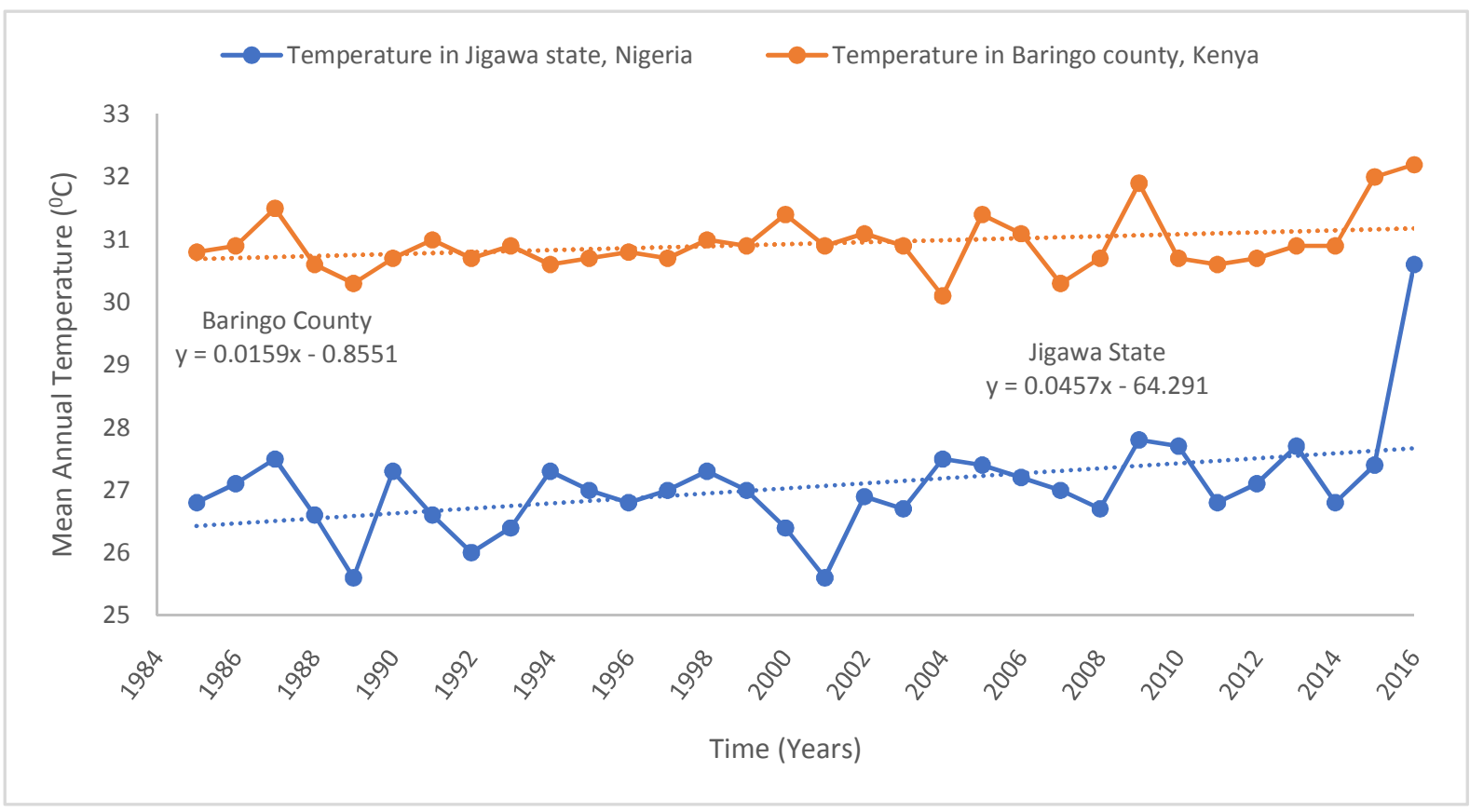

Figure 4: Mean Variations in the annual temperature in Baringo County, Kenya and Jigawa state, Nigeria

The trend of temperature from 1985 to 2016 in Baringo county, Kenya and Jigawa state, Nigeria fluctuated with slight increase in temperature overtime (Figure 4). The average annual maximum temperature in Baringo County increased from $30.8^{\circ} \mathrm{C}$ in 1985 to $31.5^{\circ} \mathrm{C}$ in 1987 , but dropped to $30.3^{\circ} \mathrm{C}$ in 1989 before it jumped to $31^{\circ} \mathrm{C}$ in 1991 . The maximum temperature of the area jumped to $32^{\circ} \mathrm{C}$ in 2015 and $32.2^{\circ} \mathrm{C}$ in 2016 . A $10.2 \%$ variation in the maximum temperature in the area was explained by changes in time. A unit change in time caused the maximum temperature to slightly change by $0.016^{\circ} \mathrm{C}$. The average annual maximum temperature in Jigawa state increased from $26.8^{\circ} \mathrm{C}$ in 1985 to $27.5^{\circ} \mathrm{C}$ in 1987 , but dropped to $25.6^{\circ} \mathrm{C}$ in 1989 before it slightly increased to $27.3^{\circ} \mathrm{C}$ in 1990 . The average annual maximum temperature in the area fluctuated steadily between $1991\left(26.6^{\circ} \mathrm{C}\right)$ and $2010\left(27.7^{\circ} \mathrm{C}\right)$ and decreased to $26.8^{\circ} \mathrm{C}$ in 2011 . An $18.95 \%$ variation in maximum temperature in the area was explained by changes in time. A unit change in time causes the maximum temperature to slightly change by $0.046^{\circ} \mathrm{C}$.
The people's perception on temperature variations in the studied area was in line with the climate data records obtained from their meteorological centres.

\section{Gender disaggregated Roles and Decisions in Household Agricultural and Socioeconomic Activities}

There exist disparity in gender roles as it pertends to household agricultural and socioeconomic activities among the rural populace in the study locations. In Baringo county, Kenya, males played dominant roles in land preparation $(59.5 \%)$, livestock keeping/feeding (56.2\%), pesticide application (69.5\%) and fence construction $(73.1 \%)$ while females played dominant roles in seed planting $(58.6 \%)$, water supply $(55.9 \%)$, domestic chores $(76.9 \%)$ and sales of agricultural produce $(60.7 \%)$. Gender equality was observed in harvesting of agricultural produce (59.5\%) (See figure $5)$. 


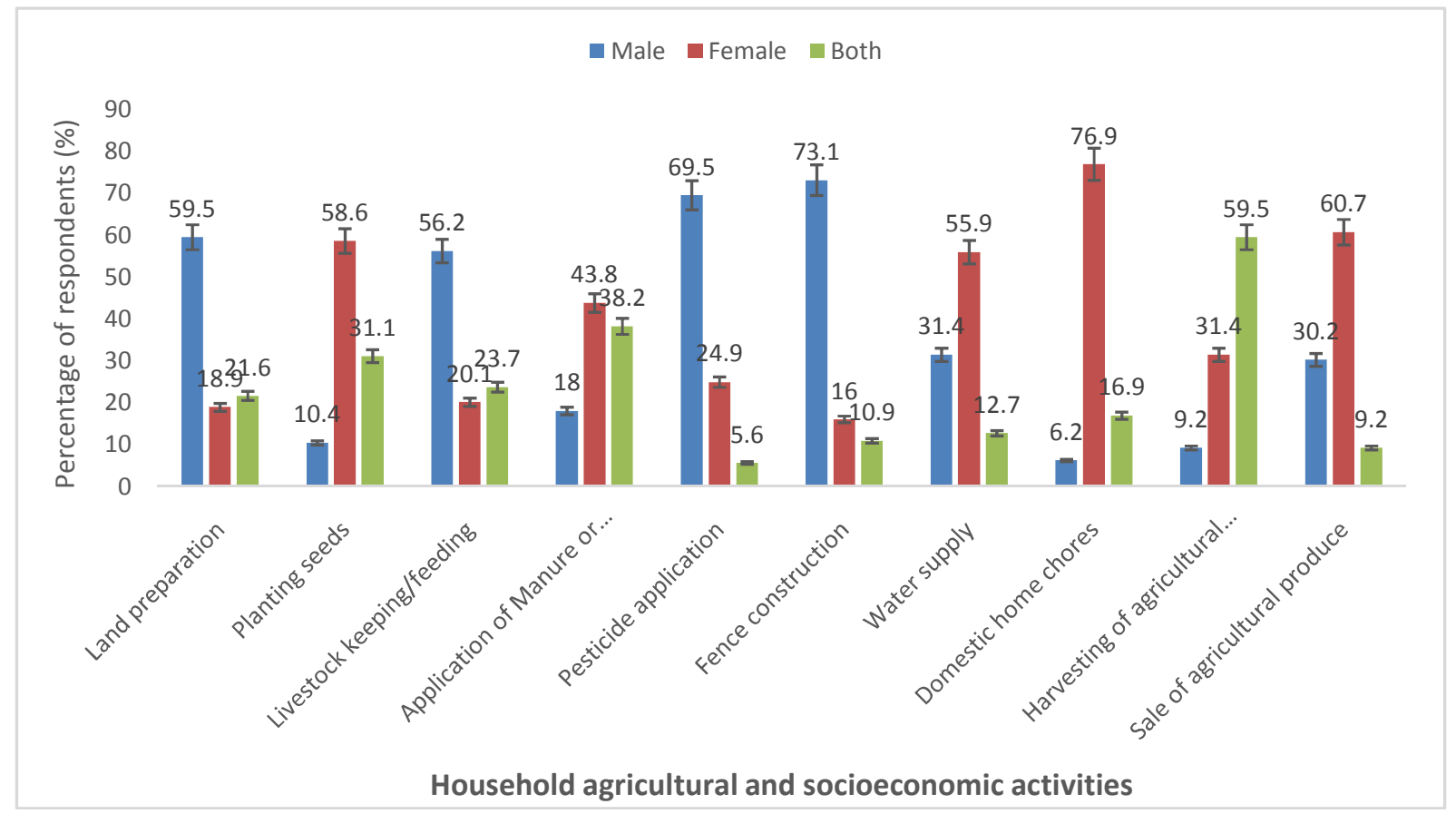

Figure 5: Gender roles in household's agricultural and socioeconomic activities in Baringo County, Kenya.

This implies that there are much gender differrential in the roles played by both males and females in household agricultural and socioeconomic activities in Baringo county, Kenya.

Similarly, the result presented in figure 6 showed that in Jigawa State Nigeria,males played dominant roles in livestock keeping/feeding (42.5\%), and fence construction $(54.9 \%)$, while females played dominant roles in water supply $(68 \%)$, domestic chores $(72.5 \%)$ and sales of agricultural produce (64.1\%). Gender equality was observed in harvesting of land preparation $(45.1 \%)$, seed planting $(64.1 \%)$, application of manure or fertilizer $(65.4 \%)$, pesticide application $(44.4 \%)$ and harveting of agricultural produce $(47.7 \%)$. This implies that there are no much gender differrential in the roles played by both males and females in household agricultural and socioeconomic activities in Jigawa state, Nigeria.

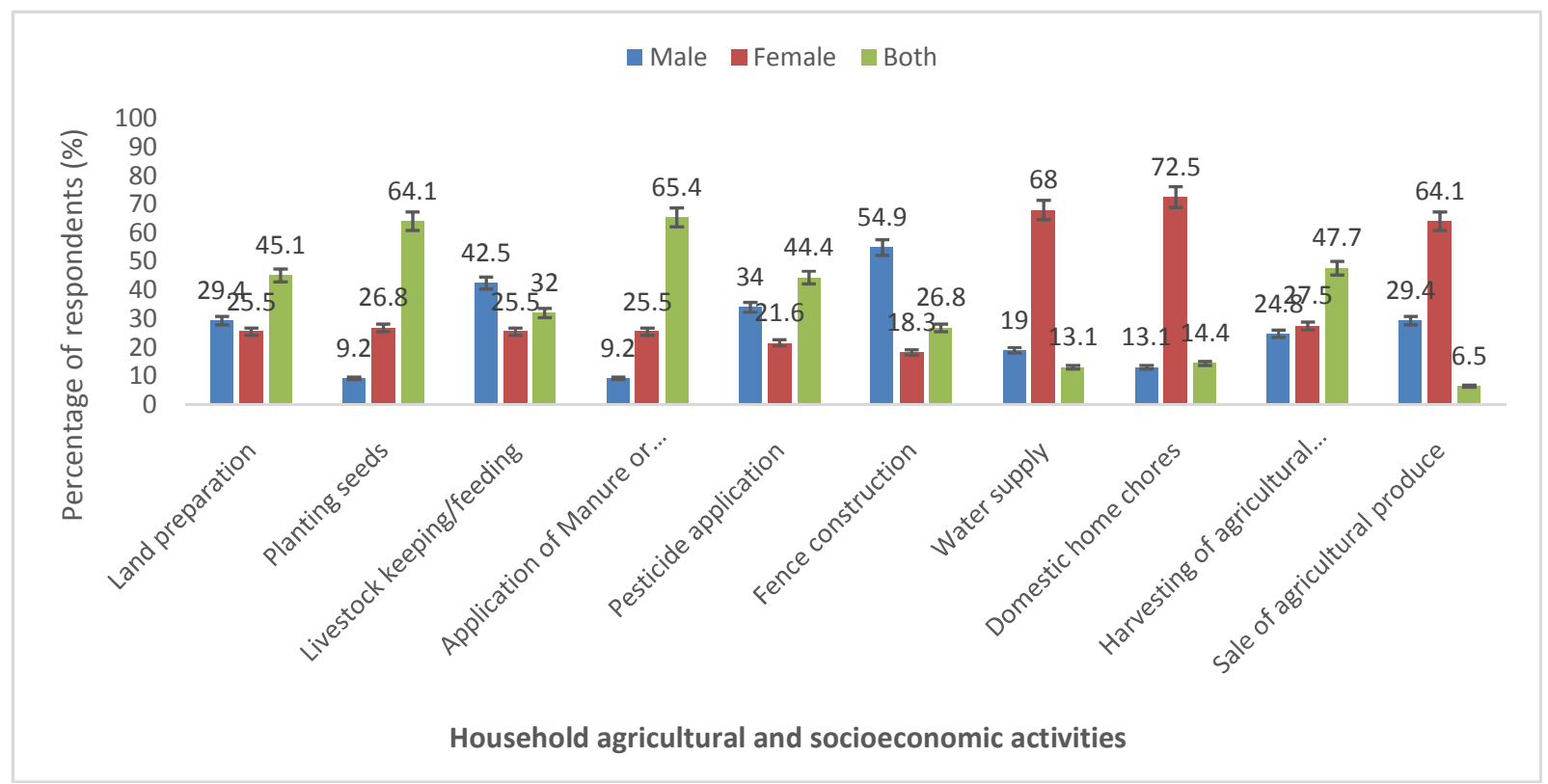

Figure 6: Gender roles in household's agricultural and socioeconomic activities in Jigawa State, Nigeria Figures 7 and 8 showed that gender differential exist in household decision making as it relates to household agricultural activities and coping strategies to adopt due to climate variability among rural populace in Baringo county, 


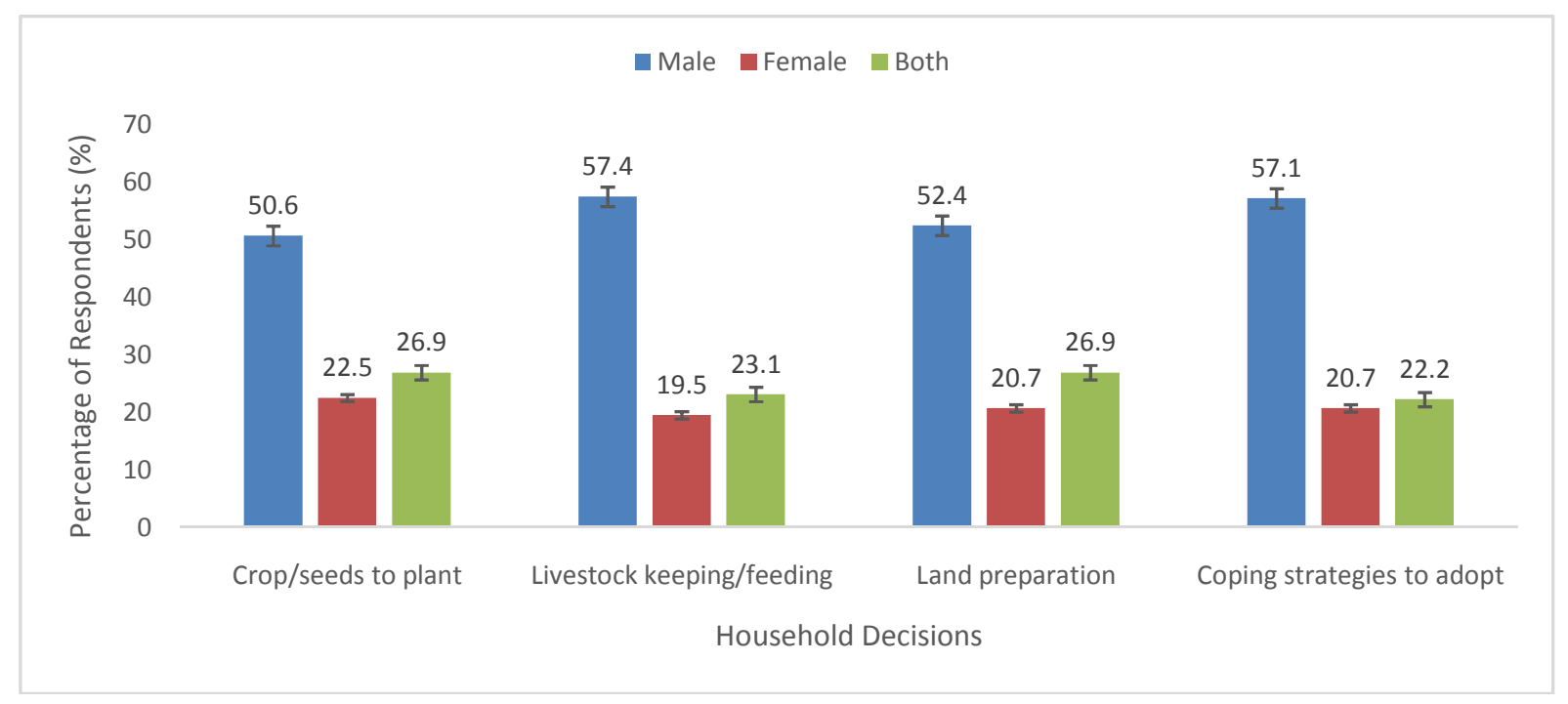

Fig. 7: Gender roles in farming household's decision making process in Baringo County, Kenya

In Baringo County, males make the most decisions on crops/seed to plant (50.6\%), livestock keeping/feeding $(57.4 \%)$, land preparation $(52.4 \%)$ and coping strategies to adopt for climate variability (57.1\%) (See figure 7$)$. In Jigawa State, males also make the most decisions on crops/seed to plant $(60.7 \%)$, livestock keeping/feeding $(51.6 \%)$, land preparation $(42.5 \%)$ and coping strategies to adopt for climate variability (58.8\%) (See figure 8 ). This shows that female decision in most of the households in the study locations is not valued as it concerns agricultural activities and climate change coping strategies. Due to gender-defined roles in society and traditional patterns of female marginalization in household, the study shows that women carry out household roles, mostly inclined with the heaviest burdens from these global changes, but are not allowed to make decisions that may address them. Gender mainstreaming in household roles and decision can offer a pluralistic approach in the long term that values the diversity among men and women, thereby promoting gender equality and achieving faster solutions to climate change in Kenya and Nigeria.

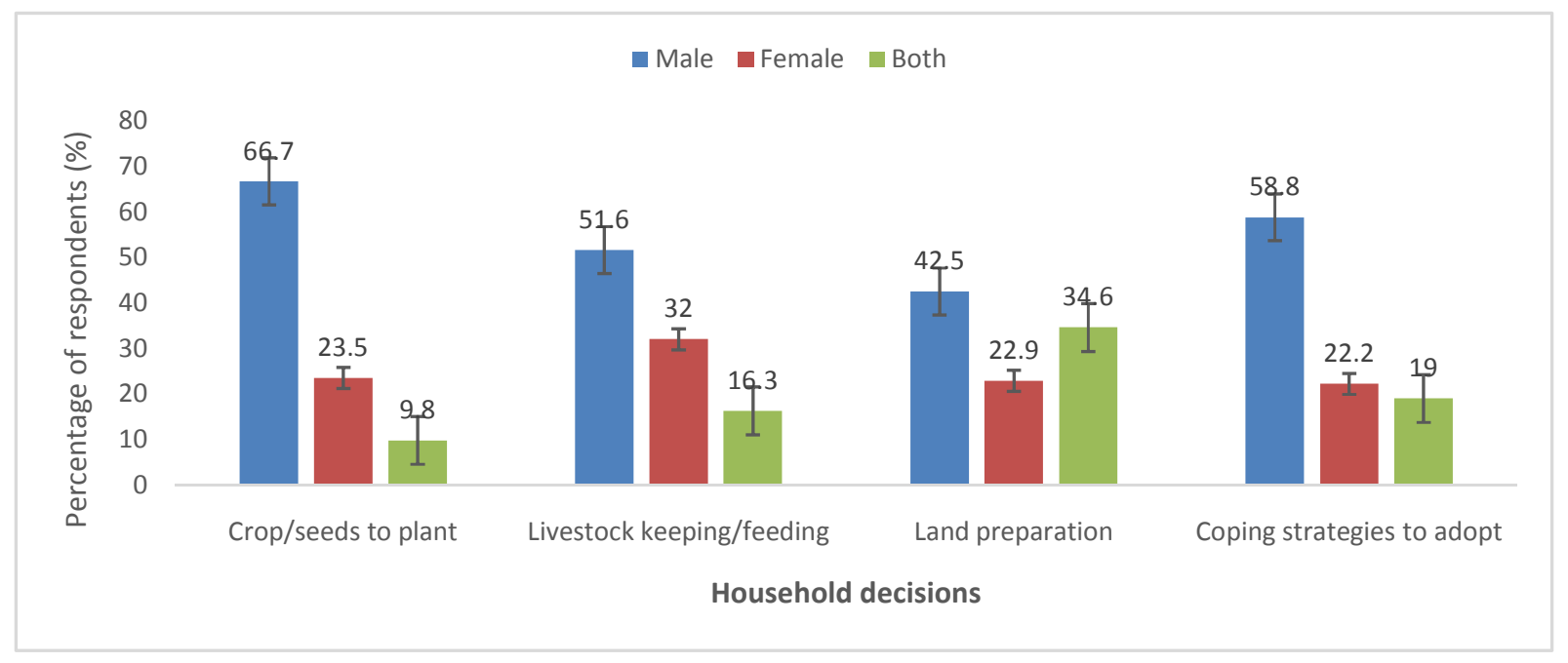

Figure 8: Gender roles in farming households' decision making processes in Jigawa state, Nigeria 


\section{CONCLUSION}

Most of the farmers are familiar with climate variability and have adopted some coping strategies to reduce the effects of the "pains" caused by climatic variability. Most of the roles and decision related to livelihood and agriculture have been influenced either positively or negatively by climate. The male gender are noted to take more decisions in the Baringo county, Kenya but it is the opposite in Jigawa state, Nigeria where there are no much gender differential in roles, as both genders take decision and carry out household activities, although the male gender carry a slightly higher percentage. This implies that the females are not allowed to take the lead in decision making in both study locations. This is detrimental to finding solutions to the effects of climate variability, as the female gender usually bears the heaviest burden caused by climate variability. However, there is need to engage the female gender in taking decisions in household and climate related issues, while information on climate variability should be readily available to farmers. This will help to assuage the effect of climatic variability on crop production, livestock rearing and livelihood activities in general.

\section{ACKNOWLEDGEMENTS}

This research has been funded by UK aid from the UK government. The author(s) wish to acknowledge the kind support of Association of Commonwealth Universities (ACU), DFID, VITAE and African Academy of Sciences (AAS) under the coordination of CIRCLE (Climate Impact Research Capacity and Leadership Enhancement), who awarded a research scholarship grant to Ezenwa Lilian I. to carry out this Research in Kenya.

\section{REFERENCE}

Adesina, F. A., 2008 Living in a severely altered world, Inaugural Lecture Series 218, lle-ife, Nigeria, Obafemi Awolowo University Press Limited.

Akinseye, F.M; Ogunjobi, K.O; Okogbue, E.C., 2012 Climate variability and food crop production in Nigeria, International, Journal of Academic Research Part A 4(5), 107-111.DOI 10.7813/2075-4124.2012/4-5/A.1.

Alemu, G.T; Ayele, Z.B. and Berhanu,A.A., 2017 Effects of Land Fragmentation on Productivity in Northwestern Ethiopia, Article ID 4509605.

Ali, A. and Erenstein, O., 2017 Assessing farmer use of climate change adaptation practices and impacts on food security and poverty in Pakistan, Climate Risk Management 16, 183194.

Antwi-Agyei, P; Stringer, L.C; Dougill, A.J; 2014 Livelihood adaptations to climate variability:
Insights from Farming Households in Ghana, Regional Environ. Change 14(1):3 -14.

Ayugi, B.O. Wen, W; Chepkemoi, D., 2016 Analysis of Spatial and Temporal Patterns of Rainfall Variations over Kenya, Journal of Environment and Earth Sciences, 6(11):69-83.

Besada, H. and Karolina, W., 2015 An assessment of the effects of Africa's water crisis on food security and management, International Journal of Water Resources Development, 31:1, 120133.

Bidoli, T.D; Isa, A.G; Shehu, B; Kezi ,D.M. and Abdullahi, M.Y., 2012 Assessment of the Effects of Climate Change on Livestock Husbandry and Practices in Jigawa State, Nigeria, Journal of Agricultural Extension, Vol. 16 (1), Pp $20-30$.

Binswanger-Mkhize, H.P., 2009 Challenges and opportunities for African agriculture and food security: high food prices, Climate change, Population growth And HIV and AIDS, Expert Meeting on how to feed the world In 2050; Food And Agriculture Organization Of The United Nations, Economic And Social Development Department.

Chung, E; Shiru, M.S; Shahid, S and Alias, N., 2018

Trend Analysis of Droughts during Crop Growing Seasons of Nigeria, Sustainability, 10, $871-884$

Cooper, P. J. M., and Coe, R., 2011 Assessing and addressing climate-induced risk in sub-Saharan rainfed agriculture, Experimental Agriculture, 47 (2):179-84.

Epstein, P., 2002 Climate change and infectious disease: stormy weather ahead, Epidemiology 13, 373-375.

FAO AQUASTAT., 2005 Irrigation in Africa in figures: AQUASTAT Survey, FAO Water Report No. 29.

Food and Agriculture Organization., 2011. The State of Food and Agriculture. Women in agriculture: Closing the gender gap for development, Rome. http://www.fao.org/docrep/013/i2050e/i2050e00. $\mathrm{htm}$

Gonzalez, X.P; Marey, M.F; and Alvarez, C.J., 2007 Evaluation of productive rural land patterns with joint regard to the size, shape and dispersion of plots, Agricultural Systems, Volume 92, No. 1-3, pp. 52-62.

Hansen, J; Sato, M. and Ruedy, R., 2012 Perception of climate change, Procedures of the National Academic of Science, USA, 109, E-2415-E2423. 
International Fund for Agricultural Development 2015. Promoting the leadership of women in producers' organizations: Lessons from the experiences of FAO and IFAD. http://www.fao.org/3/a-i5696e.pdf ISBN 978-929072-619-7

International Panel on Climate Change - IPCC, 2014 Climate Change 2014: IPCC report on climate impacts: "It's time to get serious" Synthesis Report, Contributions of Working Group I, II, and III to the fifth Assessment Report of the Intergovernmental Panel on Climate Change, Geneva: http://ec.europa.eu/clima/index_en.htm (Accessed 2018/05/25).

Ironkwe A.G. and Olojede J.C., 2012. Socioeconomic factors influencing the output of cassava farmers in Abia State Nigeria proceedings of the 26th Annual conf. FAMAN, Michael Okpara University of Agriculture Umudike October, 15th -19th, 2012:55-58.

Kenya National Bureau of Statistics (KNBS), 2010: 2009 Kenya Population and National Housing Census. http://www.knbs.or.ke/Census\%20Results/ (Accessed on 23/10/2010).

McMichael, A. J., Woodruff, R. E. And Hales, S., 2006 Climate change and human health: present and future risks, Lancet 367, 859-869.

Nhemachena, C. and Hassan, R., 2007: Micro-Level Analysis of Farmers' adaptation to Climate Change in Southern Africa, IFPRI Discussion Paper No. 714, Environment and production Technology division.

Nnamerenwa, G.C., Jessie, G.F. and Nwatu, C., 2017. Analysis of Price Differentials in the Marketing of Plantain in Abia state, Nigeria. Proceeding of the $1^{\text {st }}$ International Conference of Postgraduate Students Association of Michael Okpara University of Agriculture Umudike in conjunction with Postgraduate School Michael Okpara University of Agriculture Umudike, held on $20^{\text {th }}$ $22^{\text {nd }}$ February, 2017 at Pius Ayim Auditorium Hall, Michael Okpara University of Agriculture Umudike.

Odjugo, P.A.O., 2010 General Overview of Climate Change Impacts in Nigeria. Journal of Human Ecology, 29, 47-55.

Ostfeld, R.S; and Brunner, J.L., 20115 Climate change and Ixodes tick-borne diseases of humans, Philos. Trans. R. Soc. Lond. Ser, B Biol. Sci., 370 (20).

OXFAM 2017: A climate in crisis: How climate change is making drought and humanitarian disaster worse in East Africa.

Sawa, B.A; and Buhari, B., 2011 Temperature Variability and Outbreak of Meningitis and Measles in Zaria, Northern Nigeria, Journal of Applied Sciences, Engineering and Technology 3(5)

Souverijns, N., W Thiery, M Demuzere1 and N P M Van Lipzig. 2016. Drivers of future changes in East African precipitation. Environmental Research Lett $f e r s, 11$ (11).

Recha, J.W; Mati, B.M; Nyasimi, M; Kimeli, P.K; Kinyangi, J. and Radeny,M., 2016 Changing rainfall patterns and farmers' adaptation through soil water management practices in semi-arid eastern Kenya, Arid Land Research and Management, 30:3, 229-238,

Wasonga VO, Nyariki DM, and Ngugi RK., 2011. Assessing socio-ecological change dynamics using local knowledge in the semi-arid lowlands of Baringo District, Kenya. Environmental Research Journal.;5(1):11-17. 